\title{
Birds like it Corky: the influence of habitat features and management of 'montados' in breeding bird communities
}

\author{
Carlos Godinho • João E. Rabaça
}

Received: 2 November 2009/Accepted: 29 July 2010

(C) Springer Science+Business Media B.V. 2010

\begin{abstract}
In the southwest part of the Iberian Peninsula the dominant land-use are the Portuguese montados and Spanish dehesas, parkland forested areas of anthropogenic origin dominated by cork oak. They form a wooded matrix with open areas, scattered woodlands and undisturbed patches of Mediterranean forest and scrublands. The montados are characterized by a rich bird community. We have focus our study in a multidisciplinary approach, evaluating how management and landscape patterns influence the bird community in order to identify potential threats to its conservation. The study was conducted in the Site of Community Importance of Serra de Monfurado were $70 \%$ of the area is cork and holm oaks. We used data from 120 10-min point counts. Using variation partitioning, we determined the independent and joint effects of Forest, Management and Habitat variables. The variation captured in bird assemblage was $65.06 \%$. Most of the explained variation was related to the Habitat and Management
\end{abstract}

C. Godinho $(\bowtie)$ · J. E. Rabaça

LabOr-Laboratório de Ornitologia, Departamento de Biologia, Universidade de Évora,

7002-554 Évora, Portugal

e-mail: capg@uevora.pt

C. Godinho · J. E. Rabaça

Grupo de Investigação em Ecossistemas e Paisagens

Mediterrânicas, Instituto de Ciências Agrárias e

Ambientais Mediterrânicas, Universidade de Évora,

7002-554 Évora, Portugal variables. The explanatory variables that were highlighted as important predictors were variables that reflected tree and shrub density and cork removal. Modelling for forest species through generalized linear models (GLM) emphasize that the management plays an important role in the species distribution. The most important variables selected in models reflected cattle grazing and cork removal. Our results point out that the type of management is crucial to maintain the equilibrium in bird community associated to montados. Farmland and forest species will benefit from areas with different tree densities, small patches of Mediterranean scrubs in the understory and correct livestock numbers.

Keywords Montado - Portugal - Bird community Cork oak $\cdot$ Partition of variance

\section{Introduction}

In the southwest part of the Iberian Peninsula the dominant land-use in the countryside are the Portuguese montados and Spanish dehesas, parkland forested areas of anthropogenic origin dominated by cork oak (Quercus suber) and/or holm oak (Q. rotundifolia). These agro-silvo-pastoral systems (e.g. Pinto-Correia and Mascarenhas 1999; PintoCorreia 2000) combine the use of woodland products (timber, charcoal and cork) with cereal crops and 
livestock grazing in the understory (Blondel and Aronson 1999) and are a remarkable example of a well-adapted system to climate constrains of the Mediterranean Basin. Depending on the type of management adopted and local geographical features, the understory is often removed to prevent the development of a shrub layer in order to maintain a grass cover for cattle grazing (Díaz et al. 1997; Tellería 2001), to facilitate cork extraction and to endorse an easier access to acorns, an important food resource for wildlife and livestock from October to February.

Portugal supports $33 \%$ of the world population of cork oak ( $\approx 737000$ ha) corresponding to $23 \%$ of the country forested area (DGRF 2007). In addition to the recognized economical value of cork oak forested areas, they support a high biological diversity (Rabaça 1990; Díaz et al. 1997, 2003; Blondel and Aronson 1999; Tellería 2001; Tellería et al. 2003; Harrop 2007). Mainly as result of the mosaic created by this dynamic heterogeneous landscape which forms a wooded matrix with open areas, scattered woodlands and undisturbed patches of Mediterranean forest and scrublands (Tellería 2001; Pereira and Fonseca 2003). In the Iberian montados and dehesas the result of the increase presence of edge and open area birds it appears to compensating the loss of forest birds (Tellería 2001). This pattern of bird richness increases in woodlands southwards along the Iberian gradient, with montados and dehesas showing the highest scores was described by Tellería (2001). Although the legal protection of forest oak plantations and the fact that most of cork oak world population is located in the Mediterranean Basin (Carrión et al. 2000), designated as one of the 25 biodiversity hotspots of the world (Myers et al. 2000), this forest areas are threatened by land abandonment, by pathogenic agents and overgrazing (Plieninger 2007).

So, reliable data must be gathered in order to allow the establishment of monitoring programs to assess the relationships between biodiversity and management actions at spatial and temporal scales. The link between this knowledge and the management of this particular ecosystem allow the co-existence of biodiversity and sustainable production. We have focus our study in a multidisciplinary approach, evaluating how management and landscape patterns influence the bird community in order to identify potential threats to its conservation. For common forest species we aim to assess the most important forest features in montado areas that influence their distribution.

\section{Methods}

Study area

Our study was conducted in the Site of Community Importance of Serra de Monfurado (PTCON0031Natura 2000) (Fig. 1), in an area of 23878 ha located in the Alentejo province, southern Portugal $\left(38^{\circ} 33^{\prime} \mathrm{N}\right.$, $\left.8^{\circ} 09^{\prime} \mathrm{W}\right)$. The climate is meso-Mediterranean with hot and dry summers and moderate rainy winters (Rivas-Martinez and Loidi 1999). Average monthly temperature varies from 9 (January) to $25^{\circ} \mathrm{C}$ (July) with an annual average of $12.5^{\circ} \mathrm{C}$, the annual rainfall ranges from 600 to $1000 \mathrm{~mm}$ (Instituto do Ambiente 1999; SNIRH 2007).

Quercus suber and $Q$. rotundifolia are the dominant element of the landscape ( $\approx 70 \%$ of total surface). Other land uses include meadows, pastures and fallows, olive groves and orchards, arable crops, eucalyptus plantations, pine groves and vineyards. Shrubby areas are dominated by blackberry Rubus ulmifolius, rockroses Cistus spp. and gorse Ulex spp. In some watercourses riparian vegetation create forest galleries with deciduous trees like ash Fraxinus angustifolia, alder Alnus glutinosa, willows Salix alba, S. atrocinerea, S. salvifolia, poplars Populus nigra and, on most shaded areas, Portuguese oak Quercus faginea.

Sampling sites and bird surveys

Thirty forested sampling plots ( $Q$. suber and/or $Q$. rotundifolia), ranging in size from 16 to 93 ha (mean size $46.7 \pm 21.5 \mathrm{ha}$ ), were surveyed twice during the breeding season of 2004. In each plot two sampling sites were selected: the first near the plot center and the second at least $250 \mathrm{~m}$ apart from this. We sampled birds using point counts with unlimited distance and a counting period of $10 \mathrm{~min}$ (e.g. Blondel et al. 1981; Bibby et al. 2005). The first visit occurred between 15 March and 27 April, and the second from 10 May to 4 June. In all 120 point counts were conducted in the early hours after sunrise by the same observer always avoiding windy and rainy weather. 
Fig. 1 Location of the SCI Serra de Monfurado and forested sampling plots (dark grey). Light grey areas are 'montados'

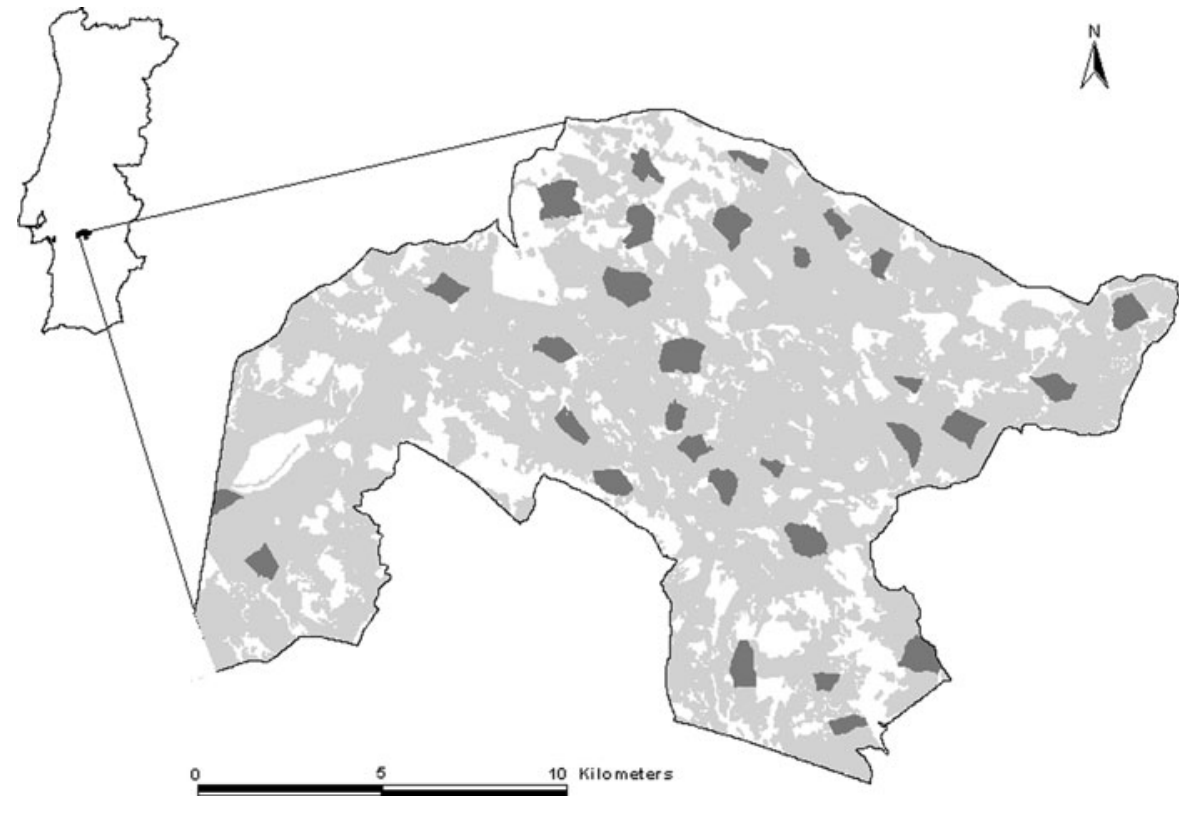

Explanatory variables

Three groups of environmental variables were recorded for each sampling site (Table 1): (1) Forest-Forest variables reflected woodland features of the surveyed plots (e.g. Quercus spp. dominance, percentage of montado affected by diseases), (2) Managementvariables include anthropogenic actions and resources exploration associated to forest management (e.g. cork removal, shrub cut), livestock (e.g. foraging area, type of cattle) and water availability (e.g. distance to the nearest water body) and (3) Habitat-Habitat variables were accessed visually at each sampling station on the same day of the bird census and reflected particular habitat features like the percentage of vegetation cover in vertical layers. Both Forest and Management variables were derived from unpublished data (ERENA 2004).

\section{Data analysis}

We used the maximum bird abundance detected in one of the two visits, which represents the minimum number of birds at that location (Bibby et al. 2005). We excluded from data treatment species with a wider spatial use of the census area (namely birds of prey, crows and insectivorous aerial flyers), or flocks. Analyzed species were chosen according to patterns of preferential habitat use of the montado: forest birds (e.g. woodpeckers, tits), farmland and hedgerows birds (e.g. common stonechat Saxicola torquatus) and shrub understory birds (e.g. sardinian warbler Sylvia melanocephala).

In order to assess the influence of each set of explanatory variables on bird community, we used the variation partitioning procedure (e.g. Heikkinen et al. 2004; Godinho et al. 2010) through canonical ordination techniques for multivariate analysis.

For forest species (Appendix) and for specific richness we developed individual models using Generalized Linear Models (GLM) (Table 3). Previously to the construction of the models, the existence of autocorrelation in our bird data was assessed using Moran's I as a function of spatial distance (Legendre and Legendre 1998). If autocorrelation is detected in the response variable, the models should account for it using an autocovariate term, and the autocorrelation in the explanatory variables should be tested (Lennon 2000; Segurado et al. 2006). Afterwards, different data reduction procedures were performed in order to avoid multicollinearity among variables, prior to the statistical modeling phase. All pairwise correlations were assessed by Spearman correlation coefficients (Tabachnick and Fidell 2001). In each pair of highly correlated variables $(r>10.71)$ (Tabachnick and Fidell 2001), only the most biologically meaningful variable was retained for further analysis. Before the GLM 
Table 1 Groups of environmental variables recorded at each one of the sampling stations

\begin{tabular}{|c|c|}
\hline Explanatory variables & Code \\
\hline \multicolumn{2}{|l|}{ Forest } \\
\hline Percentage of the dominant habitat in a $500 \mathrm{~m}$ buffer from the point count $(\%)$ & HDOM \\
\hline Area of the forested sampling plot (ha) & AREA \\
\hline Montado affected by diseases retrieved by percentage of trees affected by at least one biotic agent ( $\%)$ & MTVIT \\
\hline Percentage of trees affected by Buprestids beetles per forested sampling plot $(\%)$ & CORSP \\
\hline Percentage of trees affected by Numelaria regia per forested sampling plot $(\%)$ & NUMRE \\
\hline Percentage of trees affected by Gypsy moth per forested sampling plot (\%) & LYMDI \\
\hline \multicolumn{2}{|l|}{ Management } \\
\hline Regulated area for small game hunting (ZCT-turistic, ZCM-municipality, ZCA-associative, RG-open) (\%) & GAME \\
\hline $\begin{array}{l}\text { Years from the last cork removed }(0-\text { removed in the year of the surveys, } \\
2 \text {-in the } 2 \text { years prior to surveys, } 4-3 \text { to } 4 \text { years prior to surveys })\end{array}$ & TDESC \\
\hline Shrub removal by cutting $(\%)$ & CUTT \\
\hline Shrub removal by harrow $(\%)$ & ARROW \\
\hline Tillage $(\%)$ & SOILM \\
\hline Cover and/or fund fertilizers $(\mathrm{kg} / \mathrm{ha})$ & FERT \\
\hline Sheep density foraging per forested sampling plot $(n /$ ha $)$ & DSHEE \\
\hline Cows density foraging per forested sampling plot $(n /$ ha) & DCOW \\
\hline Swine density foraging per forested sampling plot $(n / h a)$ & DSWI \\
\hline Number of cattle species foraging per forested sampling plot (1-4) & CATTLE \\
\hline Foraging area per forested sampling plot (ha) & FORAR \\
\hline Total stocking retrieved by the total number of livestock cattle $(n)$ & TSTOC \\
\hline Distance to the nearest water body $(\mathrm{m})$ & DWAT \\
\hline Number of water points available per forested sampling plot $(n)$ & WATER \\
\hline \multicolumn{2}{|l|}{ Habitat } \\
\hline $\begin{array}{l}\text { Vegetation cover with six classes of high }(<0.5 ; 0.6-1 \mathrm{~m} ; 1-2 \mathrm{~m} ; 2-4 \mathrm{~m} ; 4-8 \mathrm{~m} ;>8 \mathrm{~m}) \\
\text { and six classes of vegetation density }(0 \% ; 0-20 \% ; 21-40 \% ; 41-60 \% ; 61-80 \% ;>80 \%)\end{array}$ & VEG \\
\hline $\begin{array}{l}\text { Dominant plant species (cork oak, holm oak, pinus, rockrose, gorse, blackberries, etc.) } \\
\text { per stratum }(<0.5 ; 0.6-1 \mathrm{~m} ; 1-2 \mathrm{~m} ; 2-4 \mathrm{~m} ; 4-8 \mathrm{~m} ;>8 \mathrm{~m})\end{array}$ & SPE \\
\hline $\begin{array}{l}\text { Shrub ecological succession with three classes }(1 \text { - shrub absence; } 2 \text { - pioneer species; } \\
3 \text { - species of advanced stages of succession) }\end{array}$ & MTS \\
\hline
\end{tabular}

Description of the variables associated with the group Forest, Management, and Habitat, as indicated

modeling, univariate models were performed and all variables with significance $P<0.15$ were retained for the following analysis (Hosmer and Lemeshow 2000). All statistical analysis was performed using SPSS 16.0 (SPSS Inc 2007).

\section{Partition of variance}

The multivariate analysis was performed using the program CANOCO for Windows, version 4.5 (ter Braak and Smilauer 2002). Bird community was related to the environmental variables using Canonical Correspondence Analysis (CCA) so as to identify which sets of environmental variables better explained the patterns of variation in bird community (ter Braak 1986). The runs were made without transformation of bird data and a forward selection of variables under an unrestricted model with a Monte Carlo test (999 permutations). Similar to Titeux et al. (2004), variables that did not contribute in a significant way to the explained variation and with weaker species-explanatory correlations were removed. Variables with an estimated $P$ value lower than 0.05 were retained. In this kind of approach, the inclusion of rare or ubiquitous species in the analysis should be avoided, as they can create modifications in the total inertia of the species dataset or distortion in the ordination (e.g. Titeux et al. 2004). We omitted from analysis species 
that were detected in less than 5 and more than 27 of the sampling stations.

Following the procedure described in Heikkinen et al. (2004), the variation in our bird dataset was decomposed into the three groups of explanatory variables-Forest, Management and Habitat-using sequential partial regression analyses with CCA (ter Braak and Smilauer 2002). The contribution of each group separately and together was evaluated through the seven CCA runs without the forward selection option, testing the significance of the first ordination axis and the significance of all axes together in CANOCO (999 Monte Carlo permutations tests).

Variation partitioning led to eight fractions: $a$-pure effect of Forest; $b$-pure effect of Management; $c$ - pure effect of Habitat; combined variation due to the joint effects of $d$-Forest and Management; e-Forest and Habitat; f-Management and Habitat; $g$ - the three groups of explanatory variables; and $U$-unexplained variation.

\section{GLM}

We used GLM to test for the effects of Forest, Management and Habitat variables on forest species and on bird community parameter (species richness). Analyses were carried out with a backward stepwise procedure to point out the most important predictors.

The species models were selected using Akaike's Information Criterion corrected for small samples (AICc) (Burnham and Anderson 2002), i.e. the best fit to the variable data set. AICc is based on the principle of parsimony and helps to identify the model that accounts for the most variation with the fewest variables: the model that best explains the data is the one with the lowest AICc (Burnham and Anderson 2002). Model fit was evaluated using $D^{2}$, a measure of the percentage deviance explained according with the formula $D^{2}=$ (null deviance - residual deviance)/null deviance (Guisan and Zimmermann 2000).

\section{Results}

In all, 74 species were recorded across the surveys, from which 54 were used to calculated specific richness and 24 met the selection criteria for CCA analysis (Appendix). The average species richness and standard deviation, per point count, was $15.70 \pm 2.96$, ranging from 10 to 24 species. The most frequent species were the short-toed tree-creeper (Certhia brachydactyla) (90\%), Sylvia melanocephala (90\%) and the less frequent crested tit (Lophophanes cristatus) $(20 \%)$, golden oriole (Oriolus oriolus) $(17 \%)$ and mistle thush (Turdus viscivorus) (17\%).

Moran's I test for the forest species modelling through GLM revealed that there is no significant spatial autocorrelation in our bird data. Therefore there was no need to incorporate a group of spatial predictor variables in the analysis of our data structure.

Community analysis — variation partitioning

Fourteen variables were selected in the community analysis (Table 2) and the amount of variation explained by these selected environmental variables was $65.06 \%$.

The decomposition of variance demonstrated that the pure effect of Habitat and Management (16.49 and $21.39 \%$ ) and their joint effect (fraction $f$ in Fig. $2 ; 8.93 \%$ ) together were responsible for the largest fraction of the variability detected in bird community (46.81\%). The amount of explained variation shared by all groups of variables represented $5.30 \%$ of the total variability.

The CCA ordination results along the first two axes after variance partition is plotted in Fig. 3 . Arrows represent the environmental variables included in the model that explain most variation in the species distribution. The proximity of bird species scores to the arrows represents the environmental condition associated to each species.

The first axis accounted for $28.5 \%$ of the extracted variance of the species-environment relationship, and $77.2 \%$ was the value explained for the four axes. The ability of environmental variables to explain variations in bird community composition is given by species-environment correlations, in this case 0.92 in axis I and 0.93 in axis II. According to the Monte Carlo test, both the first canonical axis and the whole set of canonical axes explained significant bird assemblage data $(P$ value $<0.01)$.

In the negative direction the first axis was mainly influenced by cork removed in the 2 years previously to the study (TDESC2), vegetation cover between 20 and $40 \%$ at $1 \mathrm{~m}$ high VEG2(20-40) and total stocking (TSTOC) and, in the opposite direction, by the presence of Holm oak (SPEholm), the presence of 
Table 2 Environmental variables included in CCA model and respective canonical coefficients, intra-set correlations, statistics of Monte Carlo significance test $(F)$ and the associated probability $(P)$

\begin{tabular}{|c|c|c|c|c|c|c|c|c|c|c|}
\hline \multirow[t]{2}{*}{ Variables } & \multicolumn{4}{|c|}{ Canonical coefficients } & \multicolumn{4}{|c|}{ Intraset correlations } & \multirow[t]{2}{*}{$F$} & \multirow[t]{2}{*}{$P$ value } \\
\hline & Axis 1 & Axis 2 & Axis 3 & Axis 4 & Axis 1 & Axis 2 & Axis 3 & Axis 4 & & \\
\hline \multicolumn{11}{|l|}{ Forest } \\
\hline HDOM & -0.1064 & 0.0262 & 0.5399 & 0.4218 & 0.2330 & -0.0976 & 0.3054 & 0.5921 & 1.89 & 0.025 \\
\hline AREA & -0.1270 & -0.2105 & -0.0543 & -0.1880 & 0.0202 & -0.4848 & 0.1823 & 0.0913 & 1.78 & 0.045 \\
\hline LYMDI25 & 0.1850 & -0.0628 & -0.1709 & -0.1523 & 0.4682 & 0.0168 & -0.0920 & -0.1690 & 1.96 & 0.030 \\
\hline \multicolumn{11}{|l|}{ Management } \\
\hline GAMEzct & 0.1820 & -0.1261 & 0.6929 & -0.1433 & 0.2130 & -0.1822 & 0.5796 & -0.3869 & 2.64 & 0.004 \\
\hline FERTcover & 0.4470 & 0.0842 & -0.0979 & -0.0287 & 0.3398 & -0.0846 & 0.0656 & -0.0446 & 1.86 & 0.048 \\
\hline DSWI & -0.1251 & 0.4048 & -0.1826 & 0.4217 & -0.0308 & 0.5388 & 0.1870 & 0.4563 & 2.35 & 0.014 \\
\hline TSTOC & -0.0154 & -0.1115 & 0.4818 & 0.3300 & -0.3800 & 0.1214 & 0.3464 & 0.3089 & 1.92 & 0.027 \\
\hline DWAT & -0.3381 & -0.0647 & -0.0823 & 0.0206 & -0.4162 & -0.3196 & -0.1754 & 0.1111 & 1.77 & 0.040 \\
\hline TDESC2 & -0.5430 & 0.5199 & 0.3009 & -0.0769 & -0.4022 & 0.2096 & 0.2288 & -0.4837 & 2.54 & 0.008 \\
\hline \multicolumn{11}{|l|}{ Habitat } \\
\hline VEG2(20-40) & -0.0494 & -0.0358 & -0.0074 & -0.2804 & -0.3000 & 0.1489 & -0.2022 & -0.3808 & 2.00 & 0.017 \\
\hline VEG3(0-20) & 0.2350 & -0.2631 & 0.0974 & -0.2532 & 0.0570 & -0.1743 & 0.3997 & -0.3283 & 1.64 & 0.057 \\
\hline VEG5(20-40) & 0.3350 & 0.3587 & 0.2778 & -0.1616 & 0.6365 & 0.3883 & -0.0270 & 0.2161 & 3.86 & 0.003 \\
\hline SPEulex & -0.0882 & -0.4219 & 0.1197 & 0.1550 & -0.2703 & -0.3286 & 0.2876 & 0.0572 & 1.89 & 0.026 \\
\hline SPEholm & 0.1194 & -0.4829 & -0.1419 & 0.6283 & 0.3315 & -0.3330 & -0.3184 & 0.2005 & 2.17 & 0.012 \\
\hline
\end{tabular}

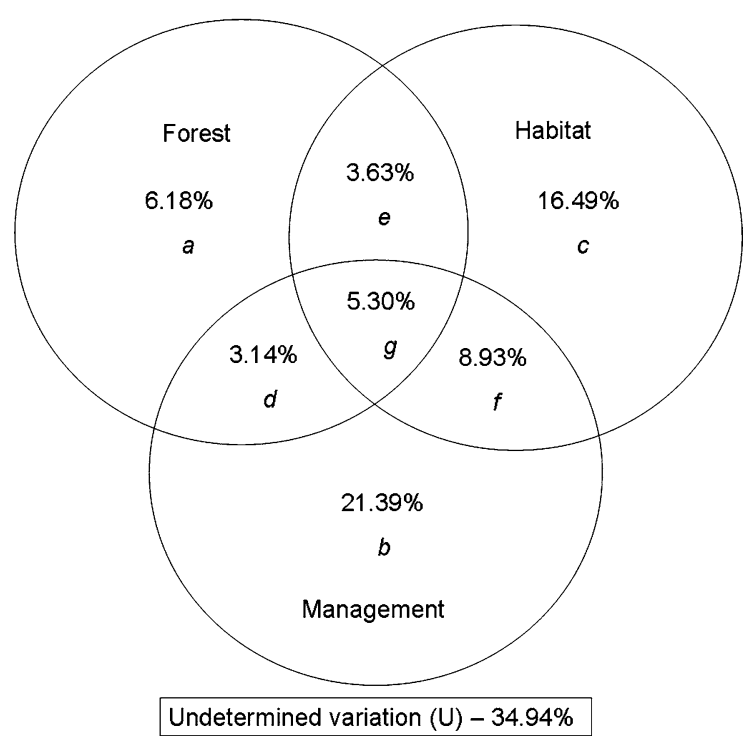

Fig. 2 Results of variation partitioning for bird community in terms of fractions of variation explained. Variation of the species data matrix is explained by three groups of explanatory variables: Forest, Management and Habitat. $U$ is the unexplained variation. $a, b$ and $c$ are unique effects of Forest, Management and Habitat variables, respectively. $d, e, f$ and $d$ are fractions indicating their joint effects trees affected by gypsy moth (LYMDI25), vegetation cover between 20 and $40 \%$ higher than $4 \mathrm{~m}$ VEG5(20-40). This axis separates plots of Cork oak with scrubs from forest patches of Holm oak with low tree cover. The second axis was, on the positive side, influenced by presence of pasture areas herd by pigs (DSWI), and the area of the sampling plot (AREA) are the variable most negatively correlated to the second axis.

\section{Modelling forest species}

For nine forest birds' species and for the species richness, minimal adequate models were calculated using GLM. Modelling was not attempt for seven forest species (wryneck Jynx torquilla, green woodpecker Picus viridis, lesser spotted woodpecker Dendrocopos minor, Turdus viscivorus, blackcap Sylvia atricapilla, Lophophanes cristatus, hawfinch Coccothraustes coccothraustes) due to scarcity of records. Interactions between species and variables are shown in Table 3. From all the set of predicted variables, 16 occurred in one or more models. Most of the variables selected represent the Management group (12 variables), three 
Fig. 3 Ordination biplot of the first two axes of the CCA for bird community. Forest variables are represented in black, Management variables in grey and Habitat variables in dashed grey (see Table 1 for variables names and appendix for species codes)

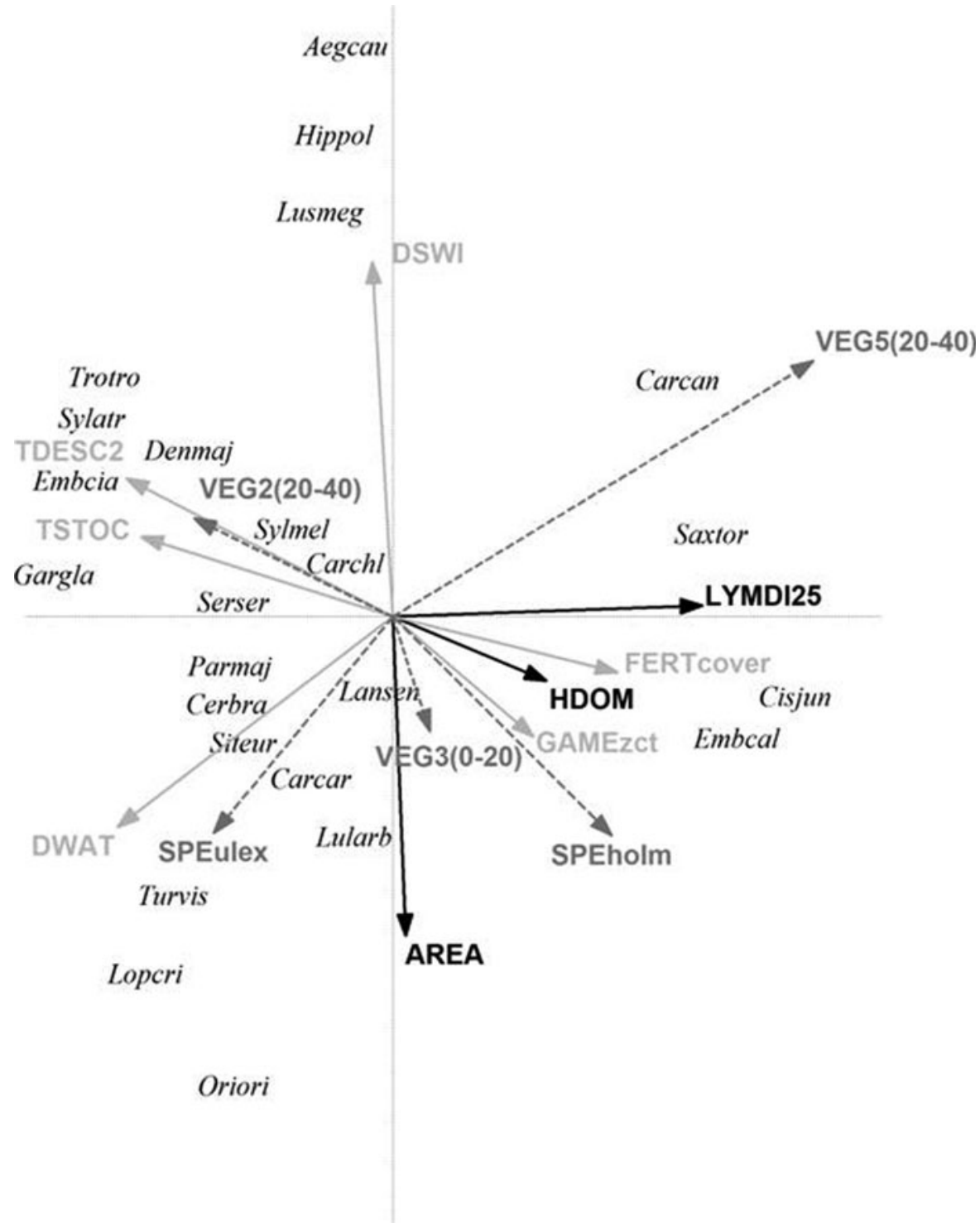

from the Forest and only one from Habitat. The most commonly identified predictor variables were cork removed at the same year of the census (TDES0) and grazing by cattle (COWS) occurring in nine and three of the species models respectively and deviance captured range between 17 and 55\%.

\section{Discussion}

Bird community

The three groups of environmental variables considered in this study captured a variation of $65.06 \%$ in bird assemblage. The largest fraction of variability captured results from the pure and shared effect of Habitat and Management variables-46.81\%. The low value explained by Forest variables suggests that species are mainly influenced by management activities in the forest and by singular habitat features at a more detailed scale.

Our results suggest that the main bird community gradient is driven by the gradient of montado density and complexity. Poorest forest areas with scattered trees, provide habitat for eurasian linnet Carduelis cannabina, Saxicola toquatus, zitting cisticola Cisticola juncidis and Emberiza calandra. This group pulls together species often associated to open area 
Table 3 GLM of forest species and species richness, in relation to environmental predictors

\begin{tabular}{|c|c|c|c|}
\hline Species & $B$ & SE & $D^{2}$ \\
\hline Dendrocopos major & & & 0.29 \\
\hline Intercept & $-3,456$ & $1,041 * * *$ & \\
\hline Shrubs removal by harrow & 2,187 & $1,053 *$ & \\
\hline High cover $(78 \%)$ of affected trees by Buprestids beetles & $-16,033$ & $2,452,146$ n.s. & \\
\hline Cork removed at more than 3 years & 0.826 & 0.067 n.s. & \\
\hline $\mathrm{AICc}$ & 59.24 & & \\
\hline Parus major & & & 0.19 \\
\hline Intercept & 0.922 & $0.202 * * *$ & \\
\hline Cork removed at the same year of the census & -0.444 & $0.226^{*}$ & \\
\hline Grazing by cattle & -0.412 & 0.221 n.s. & \\
\hline Montados with high values of pathogenic agents $(100 \%)$ & -0.743 & $0.324 *$ & \\
\hline $\mathrm{AICc}$ & 183.96 & & \\
\hline Sitta europaea & & & 0.27 \\
\hline Intercept & 1,039 & $0.204 * * *$ & \\
\hline Grazing by cattle & -0.783 & $0.277 * *$ & \\
\hline Middle tree cover in the $4-8 \mathrm{~m}$ stratum & -0.371 & 0.313 n.s. & \\
\hline Cork removed at the same year of the census & -0.464 & $0.233^{*}$ & \\
\hline $\mathrm{AICc}$ & 170.96 & & \\
\hline Certhia brachydactyla & & & 0.17 \\
\hline Intercept & 1,178 & $0.248 * * *$ & \\
\hline Cork removed at the same year of the census & -0.438 & $0.207 *$ & \\
\hline Montados with low values of pathogenic agents $(<28 \%)$ & 0.380 & 0.329 n.s. & \\
\hline High cover $(78 \%)$ of affected trees by Buprestids beetles & -0.786 & 0.856 n.s. & \\
\hline Low cover $(<20 \%)$ of affected trees by Numelaria regia & 0.460 & 0.271 n.s. & \\
\hline $\mathrm{AICc}$ & 200.30 & & \\
\hline Garrulus glandarius & & & 0.28 \\
\hline Intercept & 1,879 & $0.890 *$ & \\
\hline Percentage of occupied area by the dominate habitat & $-4,374$ & $1,482 * * *$ & \\
\hline Cork removed at the same year of the census & -0.778 & 0.521 n.s. & \\
\hline $\mathrm{AICc}$ & 82.19 & & \\
\hline Serinus serinus & & & 0.22 \\
\hline Intercept & 0.554 & $0.144 * * *$ & \\
\hline Shrub absence & $-2,191$ & $1,007 *$ & \\
\hline Cork removed at the same year of the census & -0.515 & $0.24 *$ & \\
\hline $\mathrm{AICc}$ & 179.46 & & \\
\hline Cyanistes caeruleus & & & 0.22 \\
\hline Intercept & 1,295 & $0.099 * * *$ & \\
\hline Shrubs removal by cutting & 0.342 & $0.151 *$ & \\
\hline Montados with low values of pathogenic agents $(<28 \%)$ & 0.456 & $0.181 *$ & \\
\hline Cork removed at the same year of the census & -0.287 & $0.143 *$ & \\
\hline $\mathrm{AICc}$ & 253.56 & & \\
\hline Fringilla coelebs & & & 0.20 \\
\hline Intercept & 1,547 & $0.177 * * *$ & \\
\hline Area of homogenous forest patches & 0.004 & 0.003 n.s. & \\
\hline
\end{tabular}


Table 3 continued

\begin{tabular}{|c|c|c|c|}
\hline Species & $B$ & SE & $D^{2}$ \\
\hline Grazing by cattle & -0.408 & $0.137 * *$ & \\
\hline Cork removed at the same year of the census & 0.320 & $0.136^{*}$ & \\
\hline $\mathrm{AICc}$ & 258.86 & & \\
\hline Aegithalos caudatus & & & 0.55 \\
\hline Intercept & $-1,978$ & $0.583 * * *$ & \\
\hline Shrubs removal by harrow & 1,464 & $0.630 *$ & \\
\hline Grazing by pigs & 1,835 & $0.346^{* * *}$ & \\
\hline Cork removed at the same year of the census & $-2,264$ & 0.332 n.s. & \\
\hline $\mathrm{AICc}$ & 127.04 & & \\
\hline Specific richness & & & 0.39 \\
\hline Intercept & 2,725 & $0.050 * * *$ & \\
\hline Cork removed in the 2 years prior to the census & -0.042 & 0.041 n.s. & \\
\hline Montados with low values of pathogenic agents $(<28 \%)$ & -0.097 & 0.075 n.s. & \\
\hline High cover $(78 \%)$ of affected trees by Buprestids beetles & -0.325 & $0.156^{*}$ & \\
\hline Total stocking & 0.001 & $0.000 * * *$ & \\
\hline $\mathrm{AICc}$ & 310.36 & & \\
\hline
\end{tabular}

Note: Only models with lower AICc are shown

Values for $B$, standard error, deviance explained $D^{2}$ and AICc

n.s. non significant

$* P<0.05, * * P<0.01$, *** $P<0.001$

habitats (e.g. Cisticola juncidis, Emberiza calandra) and edge habitats (e.g. Saxicola torquatus). In the opposite direction we find species that were associated with dense forest with shrubs, Turdus viscivorus, jay Garrulus glandarius, Sylvia atricapilla, rock bunting Emberiza cia, wren Troglodytes troglodytes, Sylvia melanocephala, great spotted woodpecker (Dendrocopos major), european serin (Serinus serinus), great tit (Parus major), european goldfinch (Carduelis carduelis), Certhia brachydactyla, wood nuthatch Sitta europaea, Carduelis chloris and Lophophanes cristatus. Generally, most of these species are associated to forest patches with high tree cover and to the presence of Mediterranean shrubs, commonly found in sites with low disturbances (Rabaça 1990).

These species can be divided into forest specialist species (e.g. Dendrocopos major), common forest species (e.g. Certhia brachydactyla, Sitta europaea) and shrubby species (e.g. Sylvia melanocephala), according to available ecological niches provided by the montado. These sites are also characterized by a lower intensity of grazing with livestock species turnover, and trees where the cork was removed in the last 2 years.
Three of the analysed species were not included in the previous groups. Melodious warbler Hippolais polyglotta and nightingale Luscinia megarhynchos are common breeders in riparian galleries in the South of Portugal. The relationship with areas pastured by pigs can be driven from an association between variables that were not total revealed in the analyses.

The unexplained variation in species data were $34.94 \%$. This could be attributed to unmeasured environmental variables that were not accounted for or to species that do not occupy their most suitable habitat (Titeux et al. 2004). The variables included in our analysis dealt with important descriptors directly connected to forest management, similar to other studies conducted in the same area (e.g. Galantinho and Mira 2009).

\section{Forest species modelling}

With GLM modelling we identified habitat associations for forest species (Table 3). As in community approach, variables that appeared to be more important to predict the bird species distribution are those 
reflecting the management of montado. The modelling revealed three particularly important variables: cork removed in the year of sampling had a negative coefficient in eight of the 10 models. The presence of cattle and places with high occurrence of Buprestids beetles where included negatively in three and four models, respectively.

Based on the amount of explained deviance, eight of the 10 GLM models did not describe robust models for the occurrence of each species, with less than $30 \%$ of deviance explained. These low values may be mostly due to the ability of species to use a wide range of habitats, as most of the forest species recorded can be considered forest generalists (Gregory et al. 2007). Modelling results for Aegithalos caudatus and for total richness revealed stronger associations between variables and species, with an amount of explained deviance of 55 and $39 \%$, respectively.

Time past from the last cork removal seems important to one woodpecker species (D. major) perhaps due to least perturbation of sites and to more tree similarities with old forests. Results suggest that when the cork is removed there is an abandonment of those areas by the common forest species (all species modelled), mainly due to disturbance and lack of nesting sites. With the dynamic of the montado and the cork growth the bird community seems to acquire the previous equilibrium after one breeding season. An intensive explotation of the montado, mainly with cattle leads to poor sites with less bird species present. Another set of variables important to forest birds are those describing the sanitary status of the

Table 4 List of detected species during the field work included in the analysis, common and scientific names (taxonomic order), code (based on scientific names), number of sampling forest. When the prevalence of pathogenic agents is high, forest bird species are absent.

\section{Conclusions}

Our results are consistent with the findings of Tellería (2001), showing that montados (and dehesas) act as an ecotonic habitat where a pool of forest and nonforest birds occurs. This diversity results from the forest exploration, the agriculture and foraging in scatter areas. The type of management is highlighted in this study as playing a fundamental role in the maintenance of bird communities. Areas with different tree densities, small patches of Mediterranean shrubs in the understory and well balanced livestock numbers would provide suitable habitat for several farmland and forest bird species. These species are adapted to the forest dynamic system, appearing to have ability to recover in short time even to cork removal.

Acknowledgments We thank to T. Marques and S. Gomes for invaluable comments and suggestions in an early version of the manuscript and to S. Monteiro for the English review. We also thank to two anonymous referees for they commentaries and suggestion that deeply improved the manuscript. This study was founded by PORA-Programa Operacional Regional do Alentejo.

\section{Appendix}

See Table 4.

sites where the species was detected $(N)$ and habitat specialization according to Equipa Atlas (2008)

\begin{tabular}{lllll}
\hline Species & & Code & $N$ & Habitat specialization \\
\hline Common name & Scientific name & & \\
\hline Red-legged Partridge & Alectoris rufa & ALERUF & - & Farmland \\
Common Quail & Coturnix coturnix & COTCOT & - & Farmland \\
Woodpigeon & Columba palumbus & COLPAL & - & Generalist \\
Collared-Dove & Streptopelia decaocto & STRDEC & - & Generalist \\
Great Spotted Cuckoo & Clamator glandarius & CLAGLA & - & Farmland \\
Common Cuckoo & Cuculus canorus & CUCCAN & - & Generalist \\
Hoopoe & Upupa epops & UPUEPO & - & Farmland \\
Wryneck & Jynx torquilla & JYNTOR & - & Forest \\
\hline
\end{tabular}


Table 4 continued

\begin{tabular}{|c|c|c|c|c|}
\hline \multicolumn{2}{|l|}{ Species } & \multirow[t]{2}{*}{ Code } & \multirow[t]{2}{*}{$N$} & \multirow[t]{2}{*}{ Habitat specialization } \\
\hline Common name & Scientific name & & & \\
\hline Green Woodpecker & Picus viridis & PICVIR & - & Forest \\
\hline Great Spotted Woodpecker & Dendrocopos major & DENMAJ & 11 & Forest \\
\hline Lesser Spotted Woodpecker & Dendrocopos minor & DENMIN & - & Forest \\
\hline Crested Lark & Galerida cristata & GALCRI & - & Farmland \\
\hline Thekla Lark & Galerida theklae & GALTHE & - & Farmland \\
\hline Wood Lark & Lullula arborea & LULARB & 26 & Generalist \\
\hline White Wagtail & Motacilla alba & MOTALB & - & Aquatic \\
\hline Wren & Troglodytes troglodytes & TROTRO & 19 & Forest \\
\hline European Robin & Erithacus rubecula & ERIRUB & - & Generalist \\
\hline Common Nightingale & Luscinia megarhynchos & LUSMEG & 9 & Forest \\
\hline Black Redstart & Phoenicurus ochruros & $\mathrm{PHOOCH}$ & - & Generalist \\
\hline Common Stonechat & Saxicola torquata & SAXTOR & 24 & Farmland \\
\hline Common Blackbird & Turdus merula & TURMER & - & Generalist \\
\hline Mistle Thrush & Turdus viscivorus & TURVIS & 5 & Generalist \\
\hline Cetti's Warbler & Cettia cetti & CETCET & - & Aquatic \\
\hline Zitting Cisticola & Cisticola juncidis & CISJUN & 19 & Farmland \\
\hline Reed Warbler & Acrocephalus scirpaceus & ACRSCI & - & Aquatic \\
\hline Melodius Warbler & Hippolais polyglotta & HIPPOL & 7 & Shrub \\
\hline Dartford Warbler & Sylvia undata & SYLUND & - & Shrub \\
\hline Sardinian Warbler & Sylvia melanocephala & SYLMEL & 27 & Shrub \\
\hline Blackcap & Sylvia atricapilla & SYLATR & 10 & Forest \\
\hline Common Chiffchaff & Phylloscopus collybita & PHYCOL & - & Forest \\
\hline Long-tailed Tit & Aegithalos caudatus & AEGCAU & 13 & Forest \\
\hline Crested Tit & Lophophanes cristatus & LOPCRI & 6 & Forest \\
\hline Blue Tit & Cyanistes caeruleus & CYACAE & - & Forest \\
\hline Great Tit & Parus major & PARMAJ & 26 & Forest \\
\hline Wood Nuthatch & Sitta europaea & SITEUR & 26 & Forest \\
\hline Short-toed Tree-creeper & Certhia brachydactyla & CERBRA & 27 & Forest \\
\hline Eurasian Golden-oriole & Oriolus oriolus & ORIORI & 5 & Forest \\
\hline Grey Shrike & Lanius meridionalis & LANMER & - & Farmland \\
\hline Woodchat Shrike & Lanius senator & LANSEN & 17 & Farmland \\
\hline Eurasian Jay & Garrulus glandarius & GARGLA & 13 & Forest \\
\hline Common Magpie & Pica pica & PICPIC & - & Farmland \\
\hline Spotless Starling & Sturnus unicolor & STUUNI & - & Farmland \\
\hline House Sparrow & Passer domesticus & PASDOM & - & Generalist \\
\hline Tree Sparrow & Passer montanus & PASMON & - & Farmland \\
\hline Rock Sparrow & Petronia petronia & PETPET & - & Forest \\
\hline Chaffinch & Fringilla coelebs & FRICOE & & Forest \\
\hline European Serin & Serinus serinus & SERSER & 26 & Forest \\
\hline European Greenfinch & Carduelis chloris & CARCHL & 26 & Generalist \\
\hline European Goldfinch & Carduelis carduelis & CARCAR & 25 & Farmland \\
\hline Eurasian Linnet & Carduelis cannabina & CARCAN & 18 & Farmland \\
\hline Hawfinch & Coccothraustes coccothraustes & COCCOC & - & Forest \\
\hline
\end{tabular}


Table 4 continued

\begin{tabular}{lllll}
\hline Species & & Code & $N$ & Habitat specialization \\
\hline Common name & Scientific name & & & \\
\hline Cirl Bunting & Emberiza cirlus & EMBCIR & - & Farmland \\
Rock Bunting & Emberiza cia & EMBCIA & 7 & Shrub \\
Corn Bunting & Emberiza calandra & EMBCAL & 25 & Farmland \\
\hline
\end{tabular}

\section{References}

Bibby CJ, Burgess ND, Hill DA, Mustoe SH (2005) Bird census techniques, 2nd edn. Elsevier Academic Press, London

Blondel J, Aronson J (1999) Biology and wildlife of the Mediterranean region. Oxford University Press, Oxford

Blondel J, Ferry C, Frochot B (1981) Point counts with unlimited distance. Stud Avian Biol 6:414-420

Burnham KP, Anderson DR (2002) Model selection and multimodel inference: a practical information-theoretic approach, 2nd edn. Springer-Verlag, New York

Carrión JS, Parra I, Navarro C, Munuera M (2000) Past distribution and ecology of the cork oak (Quercus suber) in the Iberian Peninsula: a pollen-analytical approach. Divers Distrib 6:29-44

DGRF (2007) Resultados do Inventário Florestal Nacional 2005/06. Inventário Florestal Nacional. Direcção-Geral dos Recursos Florestais, Lisboa

Díaz M, Campos P, Pulido FJ (1997) The Spanish dehesas: a diversity in land-use and wildlife. In: Pain DJ, Pienkowski MW (eds) Farming and birds in Europe. Academic Press, Cambridge, pp 178-209

Díaz M, Pulido FJ, Marañón T (2003) Diversidad biológica y sostenibilidad ecológica y económica de los sistemas adehesados. Ecosistemas 2003/3

Equipa Atlas (2008) Atlas das Aves Nidificantes em Portugal (1999-2005). ICNB, SPEA, PNM, SRAM. Assírio \& Alvim, Lisboa, $590 \mathrm{pp}$

ERENA (2004) Inventário florestal e cartografia de ocupação do solo do sítio da serra de Monfurado. ERENA 49 pp

Galantinho A, Mira A (2009) The influence of human, livestock, and ecological features on the occurrence of genet (Genetta genetta): a case study on Mediterranean farmland. Ecol Res 24:671-685

Godinho C, Rabaça JE, Segurado P (2010) Breeding bird assemblages in riparian galleries of the Guadiana River basin (Portugal): the effect of spatial structure and habitat variables. Ecol Res 25:283-294. doi:10.1007/s11284-009-0655-9

Gregory RD, Vorisek P, Strien AV, Meyling AWG, Jiguet F, Fornasari L, Reif J, Chylarecki P, Burfield IJ (2007) Population trends of widespread woodland birds in Europe. Ibis 149:78-97

Guisan A, Zimmermann NE (2000) Predictive habitat distribution models in ecology. Ecol Model 135:147-186

Harrop SR (2007) Traditional agricultural landscapes as protected areas in international law and policy. Agric Ecosyst Environ 121:296-307
Heikkinen RK, Luoto M, Virkkala R, Rainio K (2004) Effects of habitat cover, landscape structure and spatial variables on the abundance of birds in an agricultural-forest mosaic. J Appl Ecol 41:824-835

Hosmer D, Lemeshow S (2000) Applied logistic regression, 2nd edn. Wiley, New York

SPSS Inc (2007) SPSS 16.0 for Windows. SPSS Inc, Chicago Instituto do Ambiente (1999) Atlas do Ambiente. Direcção Geral do Ambiente, Ministério do Ambiente e dos Recursos Naturais, Lisboa

Legendre P, Legendre L (1998) Numerical ecology, 2nd edn. Elsevier, Amsterdam

Lennon JJ (2000) Red-shifts and red herrings in geographical ecology. Ecography 23:101-113

Myers N, Mittermeier RA, Mittermeier CG, da Fonseca GAB, Kent J (2000) Biodiversity hotspots for conservation priorities. Nature 403:853-858

Pereira PM, Fonseca MP (2003) Nature vs nurture: the making of the montado ecosystem. Conserv Ecol 7(3):7-37

Pinto-Correia T (2000) Future development in Portuguese rural areas; how to manage agricultural support for landscape conservation? Landsc Urban Plan 50:95-106

Pinto-Correia T, Mascarenhas JM (1999) Contribution to the extensification/intensification debate: new trends in the Portuguese montado. Landsc Urban Plan 46:125-131

Plieninger T (2007) Compatibility of livestock grazing with stand regeneration in Mediterranean holm oak parklands. J Nat Conserv 15:1-9

Rabaça JE (1990) The influence of shrubby understory in breeding bird communities of Cork oak (Quercus suber L.) woodlands in Portugal. Port Zool 1(1):1-6

Rivas-Martinez S, Loidi J (1999) Biogeography of the Iberian Peninsula. Itinera Geobot 13:49-67

Segurado P, Araújo MB, Kunin E (2006) Consequences of spatial autocorrelation for niche-based models. J Appl Ecol 43:433-444

SNIRH (2007) Meteorologia. Sistema Nacional de Informação de Recursos Hídricos, Lisboa. http://snirh.pt

Tabachnick BG, Fidell LS (2001) Using multivariate statistics. Allyn and Bacon, Boston

Tellería JL (2001) Passerine bird communities of Iberian dehesas: a review. Anim Biodivers Conserv 24(2):67-78

Tellería JL, Baquero R, Santos T (2003) Effects of forest fragmentation on European birds: implications of regional differences in species richness. J Biogeogr 30:621-628

ter Braak CJF (1986) Canonical correspondence analysis: a new eigenvector technique for multivariate direct gradient analysis. Ecology 67(5):1167-1179 
ter Braak CJF, Smilauer P (2002) CANOCO reference manual and CanoDraw for Windows user's guide: software for canonical community ordination, version 4.5. Microcomputer Power, Ithaca

Titeux N, Dufrêne M, Jacob JP, Paquay M, Defourny P (2004) Multivariate analysis of a fine-scale breeding bird atlas using a geographical information system and partial canonical correspondence analysis: environmental and spatial effects. J Biogeogr 31:1841-1856 